\title{
Adalimumab-induced acute interstitial lung disease in a patient with rheumatoid arthritis*
}

\author{
Doença pulmonar intersticial aguda induzida por \\ adalimumabe em paciente com artrite reumatoide
}

\author{
Olívia Meira Dias, Daniel Antunes Silva Pereira, Bruno Guedes Baldi, \\ André Nathan Costa, Rodrigo Abensur Athanazio, Ronaldo Adib Kairalla, \\ Carlos Roberto Ribeiro Carvalho
}

\begin{abstract}
The use of immunobiological agents for the treatment of autoimmune diseases is increasing in medical practice. Anti-TNF therapies have been increasingly used in refractory autoimmune diseases, especially rheumatoid arthritis, with promising results. However, the use of such therapies has been associated with an increased risk of developing other autoimmune diseases. In addition, the use of anti-TNF agents can cause pulmonary complications, such as reactivation of mycobacterial and fungal infections, as well as sarcoidosis and other interstitial lung diseases (ILDs). There is evidence of an association between ILD and the use of anti-TNF agents, etanercept and infliximab in particular. Adalimumab is the newest drug in this class, and some authors have suggested that its use might induce or exacerbate preexisting lLDs. In this study, we report the first case of acute ILD secondary to the use of adalimumab in Brazil, in a patient with rheumatoid arthritis and without a history of ILD.
\end{abstract}

Keywords: Lung diseases, interstitial; Arthritis, rheumatoid; Antirheumatic agents; Antibodies, monoclonal, humanized/adverse effects.

\section{Resumo}

O uso de imunobiológicos no tratamento das doenças autoimunes é cada vez mais frequente na prática médica. Terapias anti-TNF têm sido cada vez mais utilizadas nas doenças autoimunes refratárias, especialmente na artrite reumatoide, com resultados promissores. Entretanto, o uso dessas terapias está relacionado ao aumento do risco do desenvolvimento de outras doenças autoimunes. Adicionalmente, o uso de agentes anti-TNF pode determinar repercussões pulmonares, como a reativação de infecções por micobactérias e fungos e o desenvolvimento de sarcoidose e de outras doenças pulmonares intersticiais (DPls). A associação de DPl e uso dos agentes anti-TNF, em especial infliximabe e etanercepte, já foi descrita. 0 adalimumabe é a mais nova droga dessa classe, e algumas publicações sugerem que seu uso pode determinar a indução ou mesmo a exacerbação de DPls preexistentes. Neste estudo, relatamos o primeiro caso de DPI aguda secundária à utilização de adalimumabe, em uma paciente portadora de artrite reumatoide sem DPI prévia no Brasil.

Descritores: Doenças pulmonares intersticiais; Artrite reumatoide; Antirreumáticos; Anticorpos monoclonais humanizados/efeitos adversos.

\section{lntroduction}

The use of immunobiological agents for the treatment of autoimmune diseases is increasing in medical practice. Anti-TNF therapies and therapies with B-cell-depleting agents (rituximab) have been increasingly used in refractory autoimmune diseases, especially rheumatoid arthritis (RA), systemic sclerosis, and systemic lupus erythematosus, with promising results. The TNF is an interleukin secreted by activated macrophages and $\mathrm{T}$ cells as a common pathway in a series of inflammatory, autoimmune, or neoplastic responses; its blockade, whether in the form of blockade of its receptors or in the form of soluble antibodies, decreases adhesion molecule expression on the endothelial surface, decreases leukocyte migration, and inhibits the production

\footnotetext{
* Study carried out in the Department of Pulmonology, Heart Institute, University of São Paulo School of Medicine Hospital das Clínicas, São Paulo, Brazil.

Correspondence to: Olívia Meira Dias. Rua Capote Valente, 671, apto. 1401, Pinheiros, CEP 05409-002, São Paulo, SP, Brasil. Tel. 5511 3069-5000. E-mail: meiradias@yahoo.com.br Financial support: None.

Submitted: 9 November 2012. Accepted, after review: 25 January 2013.
} 
of other inflammatory cytokines. However, the use of such therapies has been associated with an increased risk of developing other autoimmune diseases, such as systemic lupus erythematosus, autoimmune hepatitis, thyroiditis, and cutaneous vasculitis. According to the literature, the use of anti-TNF agents particularly in the lung is little effective in controlling interstitial lung disease (ILD) secondary to collagenosis, and can lead to other complications, such as reactivation of mycobacterial and fungal infections, as well as sarcoidosis and other lLDs. ${ }^{(1)}$

There is evidence of an association between ILD and the use of anti-TNF agents, etanercept and infliximab in particular. ${ }^{(2)}$ Adalimumab is the newest drug in this class, and, because it is a humanized monoclonal antibody, it would have the potential advantage of being less immunogenic than its precursors. However, although adalimumab is infrequently used, some authors have suggested that its use might induce or exacerbate preexisting lLDs. ${ }^{(3-9)}$

The objective of the present study was to report the first case of acute ILD secondary to the use of adalimumab in Brazil, in a patient with RA and without a history of ILD.

\section{Case report}

A 62-year-old female patient with a 20-year history of RA had been on methotrexate, leflunomide, and prednisone. Because the articular inflammatory process persisted, we decided to start the patient on adalimumab, continuing her on methotrexate. A chest X-ray showed no changes suggestive of previous tuberculosis or signs of incipient ILD; and the intradermal (PPD) test for tuberculosis was negative $(0 \mathrm{~mm})$. One week after receiving the second dose of adalimumab ( $40 \mathrm{mg}$ weekly), the patient started experiencing dry cough, dyspnea on moderate exertion, and daily fever $\left(38^{\circ} \mathrm{C}\right)$. At that point, the results of chest X-ray, physical examination, and laboratory tests, including blood workup, were normal-hemoglobin, 13.1 $\mathrm{g} / \mathrm{dL}$; hematocrit, 39.2\%; 8,380 leukocytes (75\% neutrophils, 0.4\% eosinophil, 9.8\% lymphocytes); and 355,000 platelets, except for an increase in inflammatory markers (C-reactive protein, 326 $\mathrm{mg} / \mathrm{dL}$; reference value $<3 \mathrm{mg} / \mathrm{dL}$ ) and in ESR (67 mm, reference value $<20.2 \mathrm{~mm}$ ). Sputum smears for AFB and blood cultures were negative. The patient was started on empiric treatment with levofloxacin; however, she continued to have fever and dyspnea. A HRCT scan of the chest, performed two weeks after symptom onset, revealed ground-glass opacities, predominantly in the upper and middle lung fields, associated with areas of smooth interlobular septal thickening (Figure 1). Therefore, a presumptive diagnosis of ILD secondary to the use of adalimumab was made. We decided to discontinue the patient from the anti-TNF agent and methotrexate and to continue her on low-dose prednisone $(5 \mathrm{mg} /$ day). The patient showed progressive reduction in dyspnea, remission of fever, and normalization of inflammatory markers, without reactivation of the articular inflammatory process. Three weeks
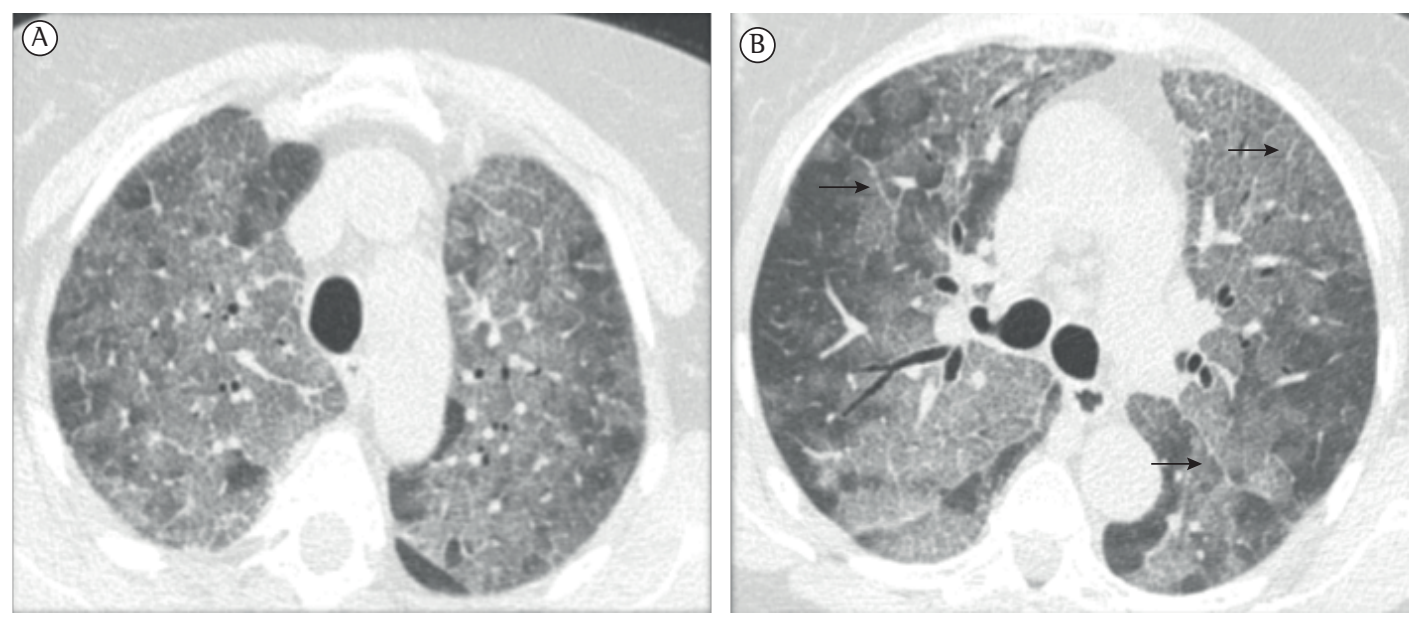

Figure 1 - HRCT scan of the chest showing pulmonary ground-glass opacities, predominantly in the upper lobes, in $\mathrm{A}$, and in the central regions, in B, associated with areas of smooth interlobular septal thickening (arrows). 
after the onset of the condition, the results of physical examination and spirometry were normal, with an $\mathrm{SpO}_{2}$ of $98 \%$ on room air. A second HRCT, performed three weeks after symptom onset, showed near-complete resolution of the ground-glass areas (Figure 2).

\section{Discussion}

The pathogenesis of anti-TNF-agent-induced lung injury remains unknown; TNF is believed to exert a pro-fibrotic action by stimulating collagen synthesis by fibroblasts and myofibroblasts. ${ }^{(10)}$ In addition, an increased Th2-type lymphocyte response, ${ }^{(7)}$ the action of $1 F N-\gamma$ unopposed by $\mathrm{TNF},{ }^{(7)}$ and the synergistic action of methotrexate are speculated to play a role in the development of lung injury. ${ }^{(8,9,11,12)}$

Clinical findings are nonspecific, and include dry cough, fever, and dyspnea, ${ }^{(2)}$ which can be progressive or more intense after each administration of the medication. ${ }^{(6)}$ Symptoms can appear from one month ${ }^{(9)}$ to three and a half years after treatment initiation. ${ }^{(7)}$ Findings on HRCT can include ground-glass opacities, foci of consolidation, reticulated patterns, and traction bronchiectasis. ${ }^{(6,8)}$

Attributing lung injury to drugs and, in the present case, to anti-TNF agents is a challenge. The diagnosis is usually presumptive, and the causal connection is determined by temporal association between drug initiation and symptom onset and by improvement after drug discontinuation, always after excluding other etiologies. In such

(A)

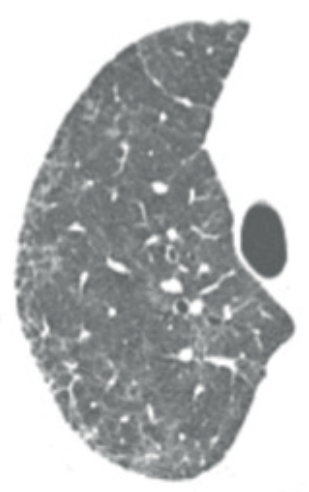

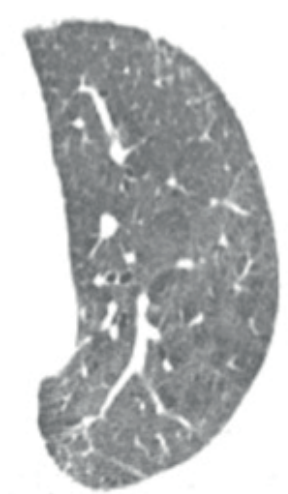

patients, in the context of immunosuppression, infection should be considered as an important differential. ${ }^{(13)}$ It should be borne in mind that the use of adalimumab has been associated with cases of pulmonary cryptococcosis ${ }^{(14)}$ and disseminated mycobacteriosis. ${ }^{(15)}$ In this clinical context, diffuse ground-glass opacities associated with intralobular septal thickening should also lead to the exclusion of other etiologies, such as viral infections or infections with Pneumocystis jiroveci, ${ }^{(16)}$ alveolar hemorrhage, pulmonary congestion, and drug toxicity due to concomitant treatment with methotrexate. Bronchoscopy and bronchoalveolar lavage aid in the differential diagnosis.

In the largest sample of patients with lung injury secondary to anti-TNF therapy, 122 cases were reported ( 3 of which were secondary to adalimumab). The mean time to symptom onset was 26 weeks. The most common histological patterns were usual interstitial pneumonia, organizing pneumonia, diffuse alveolar damage, and even lymphocytic interstitial pneumonia. of the cases that were followed up until the outcome was known, 40\% experienced improvement in ILD, 25\% had partial resolution of 1LD, and 35\% had no resolution of ILD, with death occurring in 29\% of the patients. Predictors of poor prognosis were age $>65$ years, late onset of symptoms, frequent use of other immunosuppressants (especially methotrexate), and a previous diagnosis of ILD. ${ }^{(2)}$ Despite an isolated report of improvement in ILD with the use of this medication for RA, ${ }^{(9)}$ it is currently recommended that adalimumab and

(B)

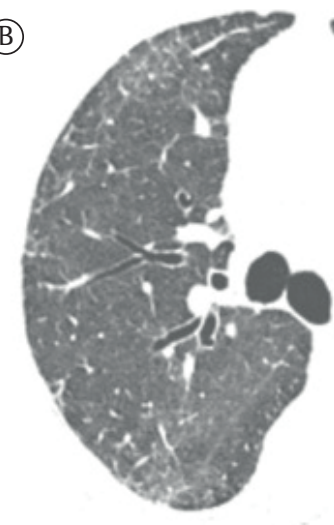

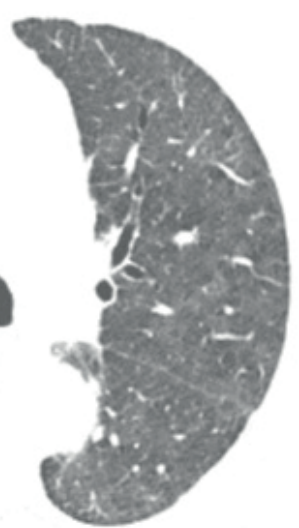

Figure 2 - HRCT scan of the chest performed three weeks after the onset of the condition. A comparative analysis of the slices shows significant spontaneous improvement in the ground-glass opacities, in relation to the first scan, in the upper lung fields, in A, and at the level of the main carina, in B. There remain faint ground-glass opacities together with slight reticular infiltrates in the subpleural regions, predominantly in the right hemithorax, especially in the middle lobe. 
other anti-TNF drugs should not be contraindicated in patients with preexisting ILD or other lung diseases but that caution should be exerted..$^{(1-3,10)}$

The course of cases of adalimumabinduced ILD can vary from complete remission after drug discontinuation alone to treatment refractoriness, ${ }^{(2,6)}$ with rapid progression to death. ${ }^{(3)}$ The use of corticosteroids or intravenous immunoglobulin, or both, should be considered in selected cases. Because of the potential severity of the patient's condition, we decided in favor of CT follow-up, with scans being performed within a short interval of each other despite the resulting radiation load.

Once it is confirmed that drug reaction has occurred, it is not recommended that the drug be reintroduced or even replaced with another drug belonging to the same class of anti-TNF agents. $^{(2,10)}$ Therefore, adalimumab, like other anti-TNF drugs, should always be considered in the list of drugs potentially causing lung injury.

\section{References}

1. Ramos-Casals M, Brito-Zerón P, Soto MJ, Cuadrado MJ, Khamashta MA. Autoimmune diseases induced by TNF-targeted therapies. Best Pract Res Clin Rheumatol. 2008;22(5):847-61. http://dx.doi.org/10.1016/j. berh.2008.09.008 PMid:19028367

2. Perez-Alvarez R, Perez-de-Lis M, Diaz-Lagares C, PegoReigosa JM, Retamozo S, Bove A, et al. Interstitial lung disease induced or exacerbated by TNF-targeted therapies: analysis of 122 cases. Semin Arthritis Rheum. 2011;41(2):256-64. http://dx.doi.org/10.1016/j. semarthrit.2010.11.002 PMid:21277618

3. Allanore Y, Devos-François G, Caramella C, Boumier $P$, Jounieaux $V$, Kahan A. Fatal exacerbation of fibrosing alveolitis associated with systemic sclerosis in a patient treated with adalimumab. Ann Rheum Dis. 2006;65(6):834-5. http://dx.doi.org/10.1136/ ard.2005.044453 PMid:16699057 PMCid:PMC1798181

4. Huggett MT, Armstrong R. Adalimumab-associated pulmonary fibrosis. Rheumatology (Oxford). 2006;45(10):1312-3. http://dx.doi.org/10.1093/ rheumatology/kel220 PMid:16935921

5. Schoe A, van der Laan-Baalbergen NE, Huizinga TW, Breedveld FC, van Laar JM. Pulmonary fibrosis in a patient with rheumatoid arthritis treated with adalimumab. Arthritis Rheum. 2006;55(1):157-9. http://dx.doi.org/10.1002/ art.21716 PMid:16463430
6. Yamazaki H, lsogai S, Sakurai T, Nagasaka K. A case of adalimumab-associated interstitial pneumonia with rheumatoid arthritis. Mod Rheumatol. 2010;20(5):51821. http://dx.doi.org/10.1007/s10165-010-0308-4 PMid:20467775

7. Dascalu C, Mrejen-Shakin K, Bandagi S. Adalimumabinduced acute pneumonitis in a patient with rheumatoid arthritis. J Clin Rheumatol. 2010;16(4):172-4. http://dx.doi. org/10.1097/RHU.0b013e3181df8361 PMid:20511978

8. Reid JD, Bressler B, English J. A case of adalimumabinduced pneumonitis in a 45-year-old man with Crohn's disease. Can Respir J. 2011;18(5):262-4. PMid:21969926 PMCid:PMC3267602

9. Komiya K, Ishii H, Fujita N, Oka H, lwata A, Sonoda H, et al. Adalimumab-induced interstitial pneumonia with an improvement of pre-existing rheumatoid arthritis-associated lung involvement. Intern Med. 2011;50(7):749-51. http://dx.doi.org/10.2169/internalmedicine.50.4748 PMid:21467710

10. Panopoulos ST, Sfikakis PP. Biological treatments and connective tissue disease associated interstitial lung disease. Curr Opin Pulm Med. 2011;17(5):362-7. http://dx.doi. org/10.1097/MCP.0b013e3283483ea5 PMid:21597375

11. Thavarajah K, Wu P, Rhew EJ, Yeldandi AK, Kamp DW. Pulmonary complications of tumor necrosis factortargeted therapy. Respir Med. 2009;103(5):661-9. http:// dx.doi.org/10.1016/j.rmed.2009.01.002 PMid:19201589 PMCid:PMC2743303

12. Golden MR, Katz RS, Balk RA, Golden HE. The relationship of preexisting lung disease to the development of methotrexate pneumonitis in patients with rheumatoid arthritis. J Rheumatol. 1995;22(6):1043-7. PMid:7674228

13. Baldi BG, Pereira CA, Rubin AS, Santana AN, Costa AN, Carvalho CR, et al. Highlights of the Brazilian Thoracic Association guidelines for interstitial lung diseases. J Bras Pneumol. 2012;38(3):282-91. http://dx.doi.org/10.1590/ S1806-37132012000300002 PMid:22782597

14. Iwata T, Nagano T, Tomita M, Suehiro Y, Nakatsuka $\mathrm{S}$, Kimura $\mathrm{H}$, et al. Adalimumab-associated pulmonary cryptococcosis. Ann Thorac Cardiovasc Surg. 2011;17(4):390-3. http://dx.doi.org/10.5761/atcs. cr.10.01561 PMid:21881327

15. Yoo WH. Multiple organ tuberculosis of lung, pleura, and peritoneum in ankylosing spondylitis during adalimumab therapy. Rheumatol lnt. 2012;32(3):787-90. http:// dx.doi.org/10.1007/s00296-009-1357-x PMid:20049444

16. Kameda H, Tokuda H, Sakai F, Johkoh T, Mori S, Yoshida $\mathrm{Y}$, et al. Clinical and radiological features of acute-onset diffuse interstitial lung diseases in patients with rheumatoid arthritis receiving treatment with biological agents: importance of Pneumocystis pneumonia in Japan revealed by a multicenter study. Intern Med. 2011;50(4):305-13. http://dx.doi.org/10.2169/internalmedicine.50.4508 PMid:21325762 


\section{About the authors}

\section{Olívia Meira Dias}

Collaborating Physician, Department of Pulmonology, Heart Institute, University of São Paulo School of Medicine Hospital das Clínicas, São Paulo, Brazil.

\section{Daniel Antunes Silva Pereira}

Collaborating Physician, Department of Pulmonology, Heart Institute, University of São Paulo School of Medicine Hospital das Clínicas, São Paulo, Brazil.

\section{Bruno Guedes Baldi}

Attending Physician. Department of Pulmonology, Heart Institute, University of São Paulo School of Medicine Hospital das Clínicas, São Paulo, Brazil.

\section{André Nathan Costa}

Attending Physician. Department of Pulmonology, Heart Institute, University of São Paulo School of Medicine Hospital das Clínicas, São Paulo, Brazil.

\section{Rodrigo Abensur Athanazio}

Attending Physician. Department of Pulmonology, Heart Institute, University of São Paulo School of Medicine Hospital das Clínicas, São Paulo, Brazil.

Ronaldo Adib Kairalla

Associate Professor. Department of Pulmonology, Heart Institute, University of São Paulo School of Medicine Hospital das Clínicas, São Paulo, Brazil.

\section{Carlos Roberto Ribeiro Carvalho}

Full Professor. Department of Pulmonology, Heart Institute, University of São Paulo School of Medicine Hospital das Clínicas, São Paulo, Brazil. 